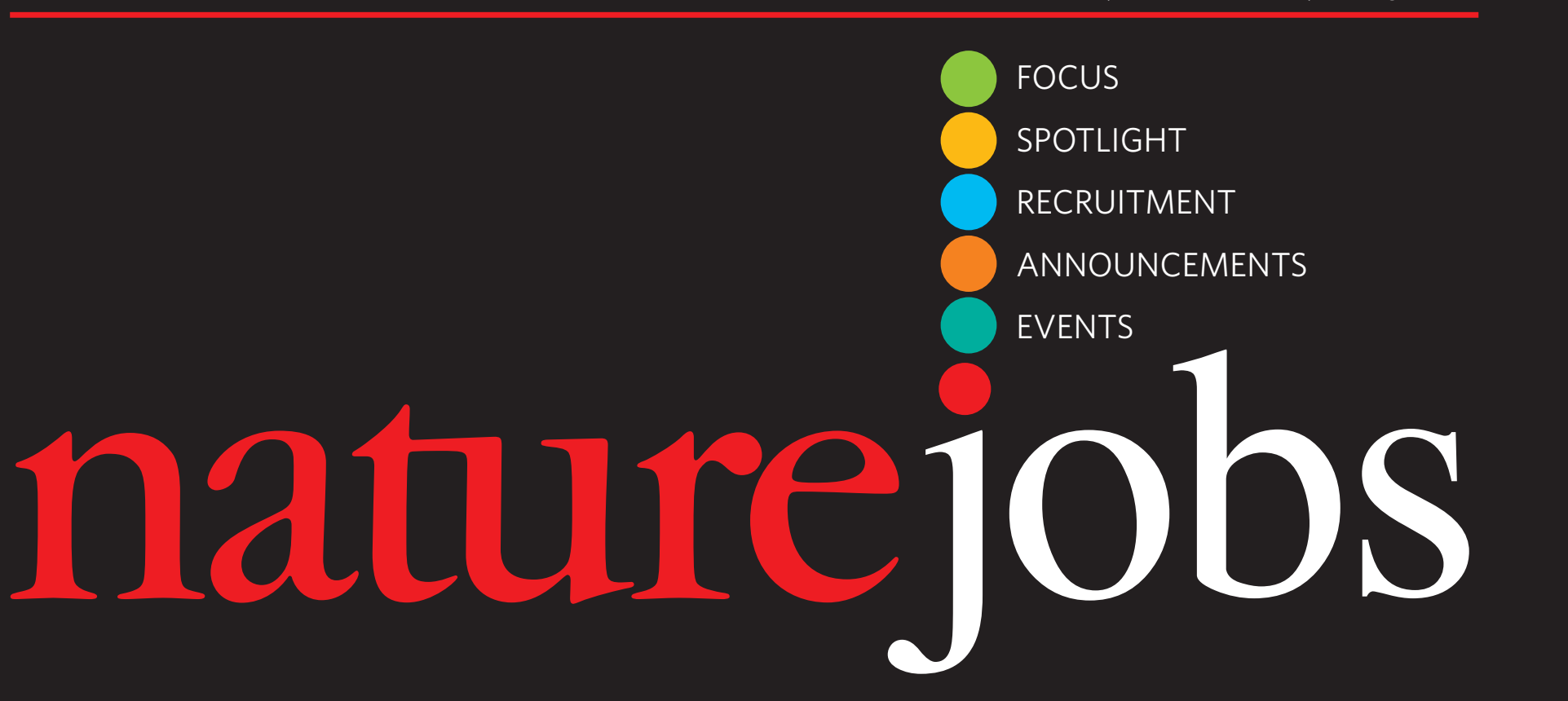

\title{
A tangential route to success
}

Sometimes tangents can lead to promising new science, as well as fresh career opportunities. That's the lesson learned by Renos Savva, this year's winner of London First's Young Biotechnology Entrepreneur Award, announced last week.

When Savva was doing his PhD at University College London, he was mostly concerned with how cells repair their DNA after it becomes damaged. But when he joined a research group around the corner at Birkbeck College in 1999, his colleagues directed his attention towards structural biology - a step away from the linear world of genetics and genomics into the three-dimensional domain of proteomics.

At the time, the group was developing technology to clone and express proteins. Traditional methods emphasized bioinformatics to guess how differences in sequences could result in different protein shapes and folds. But Savva and his colleagues felt that the approach was incomplete, because it was only educated guesswork. So they found a way to randomly sample the genome - using damaged DNA, Savva's speciality -

CONTACTS

Publisher: Ben Crowe

Editor: Paul Smaglik

Marketing Manager: David Bowen

US Head Office, New York

345 Park Avenue South, 10th Floor,

New York, NY 10010-1707

Tel: +1 8009897718

Fax: +18009897103

e-mail: naturejobs@natureny.com

US Sales Manager/Corporations: Peter Bless

Classified Sales Representatives

Tel: +18009897718
New York/Pennsylvania/

Latin America: Kelly Roman

Midwest USA/Maryland/

NIH: Wade Tucker

East USA/Canada:

Janine Taormina

San Francisco Office

Classified Sales Representative:

Michaela Bjorkman

West USA/West Corp. Canada

225 Bush Street, Suite 1453

San Francisco, CA 94104

Tel: +1415 7813803

Fax: +1 4157813805

e-mail:m.bjorkman@naturesf.com

and then clone a library of proteins that would better represent these changes.

The work had only "tenuous links" to Savva's PhD work, he says, but he nevertheless was prepared to take the plunge and follow in the footsteps of his father, also an entrepreneur. After the university helped the group obtain patent protection, the researchers spun out a company, struggled for seed money, then searched for clients. Now Savva splits his time between being research director of the company Domainex and as a research director at Birkbeck.

Savva's experience shows that left turns can lead to profitable places. But he says that tangents alone are not enough. Scientists who want to enter business also need to be comfortable with risks, and to have infrastructure in place to turn academic ideas into business opportunities.

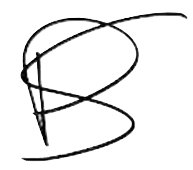

\section{Paul Smaglik, Naturejobs editor}

European Head Office, London

The Macmillan Building,

4 Crinan Street,

London N19XW, UK

Tel: +44 (0) 2078434961

Fax: +44 (0) 2078434996

e-mail:naturejobs@nature.com

Naturejobs Sales Director: Nevin Bayoumi (4978) European Sales Manager: Andy Douglas (4975)

Advertising Production Manager: Billie Franklin To send materials use London address above. Tel: +44 (0) 2078434814

Fax: +44 (0) 2078434996

e-mail: naturejobs@nature.com
Naturejobs web development: Tom Hancock Naturejobs online production: Niamh Shields

European Satellite Office

Patrick Phelan

e-mail:p.phelan@nature.com

Japan Head Office, Tokyo

Chiyoda Building,

2-37 Ichigayatamachi,

Shinjuku-ku,

Tokyo $162-0843$

Tel: +81332678751

Fax: +81332678746

Asia-Pacific Sales Director: Rinoko Asami

e-mail: r.asami@naturejpn.com 